Article

\title{
Contributions from Social Theory to Sustainability for All
}

\author{
Ramon Flecha $(\mathbb{D}$ \\ Department of Sociology, University of Barcelona, 08034 Barcelona, Spain; ramon.flecha@ub.edu
}

Received: 2 November 2020; Accepted: 25 November 2020; Published: 27 November 2020

\begin{abstract}
The sustainability of societies is an issue of utmost importance for humankind. This is reflected in the 17 Sustainable Development Goals, which highlight the main challenges that citizens face, including underserved groups, and set the path for finding solutions to overcome them. The achievement of the SDGs for 2030 is setting not only the political agenda, but also the scientific one. From the field of social sciences, an issue that remains underexplored is the contributions (or lack thereof, in some occasions) from social theory to the consolidation of more sustainable societies, including the underserved groups. In this vein, the aim of this article is to provide robust evidence on how social theory has contributed to such improvement and is still doing it. To this end, it provides an analysis of how the advancements made from social theory with social impact have contributed to the achievement of the SDGs. Alongside, this article also presents how some theories that never had social impact at their core have hindered the improvement of societies. This dual approach provides a clear picture of the role that social theory can play in the achievement of the SDGs, as well as evidence towards the overcoming of exclusionary theories with no scientific basis.
\end{abstract}

Keywords: social theory; sustainability; Sustainable Development Goals; social impact; vulnerable groups

\section{Introduction}

The scientific literature about sustainability is of high relevance for individuals and for society as a whole, as it covers a wide range of fundamental topics for human wellbeing and flourishing. However, one of the issues in this field that remains understudied is the contribution of social theories to the inclusion of underserved groups in the different Sustainable Development Goals. Nevertheless, sometimes, like in other fields of study, contributions from social theories have been quoted by authors who had not read them in depth. This has generated confusion, mistakes and, on many occasions, it has even prevented the improvement of the sustainability of our societies. Such problems have already been highlighted by the Nobel Laureate Amartya Sen, who asked himself why the most quotes of the well-known book by Adam Smith are from its first pages. From the field of sociology, we can also ask ourselves why most quotes of Weber's "Economy and Society [1], considered by sociologists as the most relevant book in the field, are also from its first pages. Social theory is only one of the required dimensions of the work towards sustainable societies which should be reinforced with rigorous readings of those theories.

Therefore, drawing on a deep commitment towards the sustainability of societies and with the focus on underserved groups, this article moves away from superficial assumptions. Its in-depth analysis not only builds on the rigorous reading of the main contributions in the field. Furthermore, it introduces the public debates on such contributions shared with a diversity of people, including some of the leading authors: Beck, Berger, Butler, Beck-Gernsheim, Puigvert, Elster, Levi-Montalcini or Erik Olin Wright. A focus is set on those theories and authors that are fostering social impact through the overcoming of the challenges that affect humankind, especially underserved groups. 
Along these lines, this article provides evidence on the contributions that have been made from some social theories towards the promotion of more sustainable and inclusive societies, in an analysis in which such contributions are linked to the achievement of some of the UN's Sustainable Development Goals for 2030. To undertake this objective, the article not only focuses on presenting the most meaningful contributions, but also signals and debunks those social theories that have been harmful to social sustainability.

\section{From Social Theory to Social Impact}

Parsons, with his co-authored book The Negro American [2], initiated, in the 1960s, a key change in his sociological theory, orienting it towards the concept of societal community. He then devoted the rest of his life to develop this concept [3,4]. In this regard, Parsons considered as positive the civil rights social movement in favor of the black underprivileged community. He learned, from that social movement, to transform and enrich his sociological theory. However, this had not been his first shift. In the 1930s, the horror he felt before Nazism and Stalinism led him to substitute, in his theory, those elements focused on social action for an already systemic functionalism, which is the best-known part of his work [5]. Even more mentioned is the role of reflection on workers' movements in the elaboration of what is studied in many universities as Marx's classical sociological theory [6].

Nevertheless, Parsons', Marx's and other classical authors' contributions to social theory have often not included reflections on the concept of sustainability. It was not until the 1980s that Beck developed his concept of the risk society in relation to the environmental movements [7]. Beck's advancements had an impact on most of the contributions that have since been made to sociological theory. These have not only consisted of theoretical reflections on sustainability in general, but more specifically on social sustainability, in a wide and rich range of ways. While Marx prioritized his focus on the underserved communities from an economic perspective [6], and Parsons [5] from the perspective of the ethnic or cultural group, Beck extended the spectrum to other identities and situations such as gender or religion.

The current priority of research programs is set on the UN's Sustainable Development Goals (SDG) [8]. The envisioned 17 SDGs affect humankind as a whole, including all vulnerable groups. Some SDGs specifically target the underserved populations (e.g., Poverty, Hunger, Decent Work), while the development of other SDGs takes these groups as a priority (e.g., Health, Education). Along these lines, through the Europe2020 strategy, the European Commission established the Horizon2020 research program [9]. This was developed around objectives based on the real needs of the citizens, with the social impact of research as a core component. Indeed, within this return to the origins of the Social Sciences and prioritizing the issue of social impact, the European Commission appointed a group of experts from different areas of knowledge. Their goal was to elaborate a report on how to evaluate the social impact of research under EU programs. The report, entitled Monitoring the Impact of EU Framework Programmes [10], established four key impact pathways to be taken into account in the assessment of the social impact of research of the next European framework program, Horizon Europe. Such approach demands $\mathrm{H} 2020$ projects funded by the EU to demonstrate their capacity to achieve social impact in extremely competitive calls.

This scenario shows that now, more than ever, citizens play a central role in the public sphere, actively contributing with their abilities to the configuration of policies and programs that respond to their needs. The goal now for science is to yield results that contribute to the improvement of people's lives and, in turn, bring closer science to citizens, from bottom-up approaches. Time and other resources cannot be invested in a research process that only takes into account the researcher's interest, while completely neglecting the main problems that citizens are currently experiencing, as represented in the SDGs. In this vein, drawing on the concept of "sociological imagination" by C.W. Mills [11], individuals make the connection between their personal life experiences (biography) and the issues affecting the society at large (history). Problems regarding poverty, hunger or gender-based violence are no longer seen only as personal troubles, but as public issues, the overcoming of which demands solutions based on scientific evidence. In other words, citizens are demanding scientists to 
implement research processes leading to social impact; that is, positively impacting the lives of citizens. Citizens are not passive actors, but active ones who want to participate in deciding their own destinies.

This creates a new scenario in which social theory is beginning to be enriched by reflection on the very diverse underserved communities. This idea can be identified in Burawoy's definition of "public sociology" [12]. According to the author, this branch within the field of sociology seeks to engage in a dialogue with citizens in order to address those issues that are of social concern. Under such an approach, sociological theory provides society with scientifically sound and useful knowledge that can be used towards the overcoming of the identified social challenges [13]. Indeed, beyond critiques regarding the professionalism and legitimacy of public sociology [14], this branch has recovered the idea of how society and social theory can contribute to the improvement and advancement of one another, a process which is now taking place much more rapidly and fruitfully than in the previous two centuries.

\section{The Right to Health Beyond Ageism}

The COVID-19 pandemic has brought to the forefront SDG 3: Good Health and Well-being to ensure healthy lives and promote well-being for all at all ages [8]. Research has made clear that healthcare for vulnerable groups is essential to the entire population [15]. This approach prevents members of privileged groups from getting infected through their inevitable interactions with the less privileged, whether it is cleaning at home or when delivering an order. However, in this very difficult situation, not only has the rejection of universal healthcare for the entire population emerged with new force, but also the stance of not caring for and "letting" the elderly die. Indeed, the greater vulnerability of older citizens and the inability of the system to recognize their value has led to a form of selection that excludes those who are not the youngest and healthiest $[16,17]$. Nevertheless, contributions made from research have shown that the stigmatization of the elderly as non-productive individuals has no scientific basis.

Rita Levi-Montalcini, Italian neurologist and Nobel Laureate in Physiology or Medicine, was actively involved in research until shortly before her death at the age of 103 . In her last works, she exposed how, in the third and fourth age, one's cognitive capacities can manifest themselves in completely new ways, and that an astronomical number of neuronal circuits can effectively be maintained at an advanced age. Furthermore, Levi-Montalcini [18] defended that old age is a period to make plans for the time that remains to be lived, whether it is one day, one month or several years, with the hope of being able to carry out the projects that could not be undertaken in the years of youth. Indeed, such an approach is in line with leading theories of adulthood, such as that of Erikson [19]. The author defined old age as the stage of Integrity vs. Despair. According to his theory, in this stage, individuals look back on their lives and wonder if they have achieved, or at least come close to, what their dreams had been. When the answer is positive, the individual feels fulfilled and reaches integrity. When the answer is negative, the individual falls into despair [19]. Another of Erikson's contributions of great relevance for the current times is the need to maintain a generative function during aging. This function gives meaning to a vital commitment that keeps the individual alive and prevents him from falling into despair. In addition, Levi-Montalcini also denounces how the association of the old age with decline has only been supported by a few authors, who, in addition, do not belong to the guild of geriatric scientists. Such authors emphasize the negative and pessimistic aspects of aging from positions which are not based on scientific evidence. As an example, Levi-Montalcini [18] highlights how Simone de Beauvoir defined aging as a kind of shameful secret, a forbidden subject. Beauvoir, in her treatise entitled Old Age [20], said that the vast majority of people welcome old age with sadness or with rebellion, which inspires more repugnance than death itself.

Therefore, the sustainable development of societies cannot be at the expense of the death of the most vulnerable, and no state of emergency can be used to legitimize or cover up the failure to comply with the basic human right to life. Indeed, as a response to this situation, a social and intellectual movement in defense of the right to life of the elderly has also emerged with unprecedented force, 
with theorists and sociologists playing an important role in it. The dramatic numbers of elderly people who have died in nursing homes or in hospitals, without being given full life-saving care, encouraged the release of the manifesto There is no future without the elderly. Appeal to re-humanize our societies. No to a selective healthcare system, promoted by the Community of Sant'egidio [21] in Rome. This manifesto was signed by intellectuals from all over Europe, including the well-known philosopher and sociologist, Jürgen Habermas. The statement denounces a model of selective healthcare that arises from a utilitarian mentality that considers the life of the elderly to be residual. The authors of the manifesto strongly reaffirm the principles of equal treatment and the universal right to healthcare that has been achieved over the past centuries. Their appeal reflects how this pandemic is a time to dedicate all the necessary resources to the protection of as many lives as possible. Moreover, they put forward the idea that democratic and humanitarian ethics in health are based on not making a discrimination between people, including ageism.

\section{Quality Education and No Poverty}

The contributions that we scientists must make towards the overcoming of situations of extreme need throughout the world is to put ourselves at the service of humanity through research aimed at social impact. Indeed, having social impact at the very core of research sets the focus on both, the improvement of society, and citizens reaching the goals marked by citizenry (such as the Sustainable Development Goals). This idea was stressed by Federico Mayor Zaragoza, former UNESCO president in 2010, in the Science against Poverty Conference in La Granja (Spain) [22]. Mayor Zaragoza said that he would never again attend a conference where the main outcome of which was yet another diagnosis on poverty. According to him, an autopsy is the best diagnosis there is, but it always comes far too late. In this vein, he put forward the idea that there is always an opportunity for improvement, and that is where the focus of scientific contributions should be.

The global crisis caused by COVID-19 has not only taken a toll on health systems around the world, but is also pushing many more people below the poverty line, with hunger hitting the most needy countries in the world. SDG 1: No poverty and SDG 2: Zero hunger are two basic and interrelated objectives to achieve by 2030 under the strategy of the Sustainable Development Goals. Amartya Sen [23] understood poverty not only as a lack of income (that usually identifies it), but also as the deprivation of basic abilities. This approach highlights how there are other factors (not only economic) influencing in the deprivation of abilities (and consequently leading to real poverty). Quality education for all and a public healthcare system in a democratic regime are key factors in the overcoming of poverty. In Sen's own words, "the more inclusive to reach of basic education and healthcare, the more likely it is that even those potentially poor would have a better chance of overcoming penury" [23].

The improvement of basic healthcare and education not only increases the quality of life directly, but also the ability of a person to earn an income [24]. The better the education and healthcare coverage, the more likely it is that poverty will be overcome [25]. For this reason, the advancement towards more sustainable societies demands, as well, equal rights of access and participation to quality education. This corresponds to SDG 4: Ensure inclusive and equitable quality education and promote lifelong learning opportunities for all. However, despite efforts being made, schooling systems all over the world are currently facing new challenges as a result of the pandemic. Many schools have had to close for some months, and others may soon have to go through this process, again or for the first time. This situation has forced teachers and schools to step up in the implementation of online training and has pushed them to find solutions to the newly emerging problems. The strain has been especially hard on children from socially vulnerable groups [26], who have less access to the needed resources to thrive.

From reproductionist theories in education [27], nothing can be done from schools to overcome the educational inequalities that the pandemic has multiplied. Indeed, the educational system is a mere reproducer of inequalities that condemns the children of the most vulnerable families to social determinism. Under this approach, the role of schools as guarantors of social and economic opportunities is denied to the most vulnerable populations. The productive and transformative 
character of schools is forgotten, under the assumption that only families and children with higher social and cultural capital can successfully progress. For Bourdieu, people with high cultural capital (classical culture) are the ones defining "good taste" in a given society, while those with less cultural capital (popular culture) accept this imposition of tastes. In addition to this stereotypical view, the author also argues that people with less cultural capital cannot increase it due to their lack of means [28].

Nevertheless, this deterministic and elitist vision clashes with transformative educational actions, such the Dialogical Literary Gatherings (DLG). In these, participants enjoy reading and debating the literary classics [29]. The first DLG was created before 1980 at the Adult School of la Verneda-Sant Martí, in a working-class neighborhood in Barcelona [30]. People with no academic background read and critically interpreted books such as James Joyce's Ulysses, Kafka's Metamorphosis or de Cervantes' Don Quixote, challenging elitist visions such as Bourdieu's. Since then, this educational action has been transferred to early childhood, primary and secondary schools, and health centers, as well as to a great diversity of social and educational associations.

Currently, DLGs are being carried out in more than 9000 schools in 14 countries in Europe and Latin America. In these countries, during the school lockdown caused by the pandemic, DLGs have been one of the most implemented educational actions online, in many cases, with the participation of students attending schools in disadvantaged contexts [31]. These schools, organized as Learning Communities, have sought different ways of ensuring that all children have access to an electronic device. For example, some schools have created working committees integrated by teachers, community organizations and families that have been in charge of creating solidarity networks to collect devices and ensure that no child is left without an Internet connection [32]. Thus, in a moment of special vulnerability, schools have promoted high-quality learning through educational actions based on scientific evidence. Moreover, the principles on which DLGs are based, such as egalitarian dialogue and solidarity, have also contributed to the creation of supportive and protective environments that have broken the feeling of isolation that can emerge in lockdown situations [31,32].

\section{Gender Equality}

Another key challenge for the sustainability of our societies is related to SDG 5 on Gender Equality: Achieve gender equality and empower all women and girls. Gender inequalities, as many others in society, exist not because they are intrinsic to human nature, but because they have been socially constructed. Indeed, according to Berger and Luckmann [33], through the process of socialization, individuals internalize human products that were originally external. This set of understandings, which ranges from queuing to enter the cinema to accepting gender imbalance, relies on meanings constructed by people.

In patriarchal societies, many women, like most Roma women, find themselves in a situation of triple discrimination due to their lack of academic background, to belonging to a cultural or ethnic group that suffers discrimination, and to being a woman [34]. Nevertheless, the spaces for public debate on issues affecting them have often been under the leadership of academic women who tended to forget the discriminatory situation suffered by those other women who do not belong in the academic world. Moreover, some academic women, who demanded equal salaries for men and women, had in their home migrant cleaning-ladies without contracts or healthcare coverage. Internationally renowned feminists such as Judith Butler, Elisabeth Beck-Gernsheim and Lídia Puigvert [35] already pointed out two decades ago the importance of including all women and girls in the struggle for gender equality. Indeed, the debate promoted by these authors [35] promoted a feminism of all women, where academic women contributed to create spaces for dialogue, so that all women could express their voices, especially those who had been silenced in the public debate because they did not have an academic education.

Thanks to the opening of these dialogic spaces, it has become evident the need to address the prevention and overcoming of gender-based violence as a key element to reaching gender equality. 
In this vein, research has shown that through secondary socialization, which occurs beyond the family, social meanings can be changed through interactions [36]. This is the basis of the preventive socialization of gender-based violence. In this vein, in recent years, the social sciences and socio-neuroscience have analyzed the existence of a coercive dominant discourse (CDD) that relates violent people and attitudes to attraction, desire and excitement [37]. At the same time, this coercive dominant discourse associates egalitarian and non-violent people as less exciting [38]. Furthermore, research from the field of masculinities has also allowed the identification of two models of masculinity associated with gender-based violence, and one associated to its overcoming [39]. Regarding the former, these include the Dominant Traditional Masculinity and the Oppressed Traditional Masculinity, two sides of the same coin. The third model, defined as the New Alternative Masculinity (NAM) model, is represented by men who are attractive, defend equality and are actively engaged against gender-based violence. Indeed, NAM men break the double standard of the CDD that associates violent men with attraction and excitement, and non-violent men with kindness but not desire. Jesús Gómez, in his book Radical Love [40] and other research from the perspective of the preventive socialization of gender-based violence [41-43] have identified the main characteristics that NAMs share. These include self-confidence, strength and courage as strategies to confront the negative attitudes of traditional dominant masculinities associated with violence. As well, NAM men explicitly reject double standards, being not only good men, but also attractive and desirable because of their active attitude against gender violence [39,41,42].

Another manifestation of gender violence that requires an urgent response is that of child abuse. Strong positioning of society breaking the silence and complicity with abusers is urgently needed. At the beginning of 2020, the book Le Consentement by Vanessa Springora [44] was published in France. In the publication, she reveals that she was abused by the renowned writer Gabriel Matzneff since she was a child. The story denounces the complicity of the many French intellectuals who knew about these abuses, and not only kept silent about them, but also justified and defended them. That complicity remained written for history in the declaration that Matzneff himself admitted having written in 1977, and which was signed by more than 60 French intellectuals, including Simone de Beauvoir and Jean Paul Sartre [45]. Soon after, in the French parliament, Michel Foucault joined as a member of the commission that debated some aspects of the modification of the Penal Code in relation to sexual crimes. The ideas proposed by him, such as the elimination of the age of consent and the non-identification of rape as a sexual crime, were reflected in the interview with Foucault, Danet and Hocquenghem [46]. Although debates like this are far from being a reality in the parliaments of today's democratic societies, much remains to be done to ensure that the global citizenry takes a stand, by breaking the impunity of abuse and defending children against the abuser.

Since the beginning of the feminist movement, the social advances towards gender equality and against gender-based violence have been achieved by the joint work of women and men. The widespread assumption that it has been all women against men is false and not based on scientific evidence. A well-known example is the story that has attributed to Mary Wollstonecraft, with her work Vindication of the Rights of Women in 1792 [47], the beginning of the defense of women's rights. However, it was Nicolas de Condorcet who had already defended these three years earlier in an article on women's right to vote [48], just as he continued to defend that idea in his book On the Admission of Women to the Right to Citizenship, published in 1790 [47]. What Mary Wollstonecraft had published in 1790 was the Vindication of Men's Rights [49]. Inaccurate stories such as this one do not help to advance gender equality and overcome gender violence. In cases of violence against women, there are women and men against the harassers, and men and women against the victims and survivors. The idea that feminism is a movement of all women against all men because all men are sexist is very popular with harassers, as it serves to attack men who are involved with women in the fight against sexual harassment.

\section{Decent Employment}

The current scenario of the pandemic has evidenced the differences that exist between and within territories, regarding their capacity to manage the crisis and come up with solutions for the issues 
that citizens encounter [50]. In such a scenario, SDG 10, centered on reducing inequalities within and among countries, has gained special relevance. In this vein, while some governments have managed to control the situation from the very beginning [51-53], minimizing the loss of lives and preserving the economy, others seem to struggle in every step of the way. These include not only measures regarding public health, but also social and economic ones, such as those that fall into the scope of SDG 8: Promoting sustained, inclusive and sustainable economic growth, full and productive employment and decent work for all. In addition, one must take into account how the most vulnerable populations and territories are especially affected by the current situation, finding themselves with fewer opportunities to promote the access to decent jobs, maintain employment levels and create new jobs. Merton [54] conceptualized the Matthew Effect using a verse in the Gospel of Matthew, regarding the idea that more is given to those who have more, while the people who have less receive less.

However, the status quo can be challenged under the right conditions. In this vein, Wright's theory of transformation highlights three key elements in achieving such an end: equality, democracy and sustainability [55]. The last one is understood by Wright as the equal provision of goods and services over time. Such provision also includes future generations, in order to guarantee that these can keep at least the same life standards of the present generation. Since 1991, Wright has shed light on social realities that defy all predictions and demonstrate that transformation is possible. He defined such realities as Real Utopias [55]. A real utopia is emancipatory, it flees from skepticism and fatalism, and it has the potential to transform social institutions and social systems. In order to achieve them, it is necessary to envision a viable desired alternative to the current reality, which requires an analysis of the structural conditions where it is based and the relative power of the social actors involved to transform the current reality [55].

Erik Olin Wright visited Spain to analyze transformative non-capitalist experiences fighting against inequalities. He travelled to Arrasate (Basque name of Mondragon) to visit the Mondragon Corporation. He spoke to different managers within the corporation, to all the trade unions, to very diverse types of workers and to those who are more against these cooperatives. He was also able to visit the facilities of one of the largest industrial companies in the Group. He was impressed by Mondragon Corporation, and included this experience in his publication Envisioning Real Utopias [55]. In these times of uncertainty and with a global economic crisis, Mondragon Corporation is an example of how it is possible to promote the inclusive and sustainable economic growth of a region, creating employment and decent work for all [56]. The geographical area with more of the group's cooperatives has the smallest income inequality in the world, because the cooperatives provide employment and invest a part of their benefits in the region. At the same time, the Corporation maintains the employment of all members of the cooperative. Even when a cooperative crashes, all cooperative members are relocated in other cooperatives of the Group. This resilient mechanism makes it possible to maintain employment levels despite an economic crisis. Furthermore, Mondragon Cooperatives are contributing to reduce inequalities not only in Arrasate, but also in other regions of Spain and internationally. The direct participation of all cooperative members in equal terms (one person, one vote, as main democratic principles) is directly related with the power of transformation of this real utopia, an example of a sustainable alternative that guarantees decent employment for all members of society [56].

\section{Living Together, Leaving in Peace}

When Habermas visited Porto Alegre he was impacted by the "orçamento participativo" (participatory budget) movement. In this movement, he could see reflected, in a practical way, the main components of a participative democracy not far away from a deliberative one $[57,58]$. The demands of the participatory budget were based on an assembly and self-management movement which, on the basis of citizen participation, advocated for an extension of the civil rights of the population. Involving citizens in important decisions such as the distribution of the budget in a given municipality, which has been taking place since the beginning of the 1980s, is clearly in line with what 
it would take to achieve SDG 11, Sustainable Cities and Communities, the main goal of which focuses on "making cities and human settlements inclusive, safe, resilient and sustainable".

In participatory social movements, citizens take an active, informed and critical role. In this sense, decisions are not left in the hands of experts who want to impose their visions from top to bottom, but rather carried out in an egalitarian way. Beck [59] explained this social turn through his conceptualization of the demonopolization of expert knowledge. Through this conception, the author broke with the idea of an expert as someone being far removed from society. Conversely, he pointed out that an expert should be recognized as such only to the extent that he brought his knowledge closer to the citizens. Besides, moving forward in the achievement of sustainable cities demands not only counting on the involvement of people in debating their budgets, but also contemplating the risks that the new modernity entails. In this vein, Beck [7] introduced the notion of manufactured risks, derived from modernity, making clear both their capacity to cause irreversible damage and their invisibility. The often irreversibility of such risks and their invisibility, for many, demands the intervention of experts that provide assistance towards their detection and eradication. Such action requires the accumulated scientific knowledge, and the need for scientists to bring their knowledge closer to the citizens, on an equal position.

Furthermore, living together also requires the capacity to effectively deal with conflict and promote peace. Nevertheless, according to data provided by UN [60]: 100 civilians are killed in armed conflicts every day, despite protections under international laws (... ) Already in 2019, the number of people fleeing war, persecution and conflict exceed 79.5 million, the highest level ever recorded and COVID-19 implications further threaten global peace and security. Addressing such issues becomes a key element in the achievement of SDG 16, Peace, justice and strong institutions, focused on the promotion of peaceful and inclusive societies for sustainable development, providing access to justice for all and building effective, accountable and inclusive institutions at all levels. In such contest, dialogue emerges as the fundamentally human tool to reach understandings and advance towards inclusion and problem-solving.

However, postmodernist theories have attacked dialogue, arguing that all social relations are based on power [61,62]. Such understanding is based on Nietzsche's negative views on democracy. The author considered, as factors of declining vitality, "the rise of democracy, international courts of arbitration instead of wars, equal rights for women" [63]. Indeed, the notion of freedom in Nietzsche is directly related to the same kind of relativism behind the "Brotherhood of Assassins"' well-known slogan "nothing is true, everything is permitted" ... Certainly that was freedom of the mind (des Geistes), with that the termination of the belief in truth was announced ... " [63]. Progress towards peaceful and inclusive societies cannot be made from an obsolete traditional modernity in which the powerful groups are the ones who establish the values and norms by imposing them, making use of their power. However, less can be achieved from the messages of postmodernity, in which there are no good values and in which peace and dialogue are considered power claims at the same level of war and violence. In this line, Jon Elster [64] criticized this cynical vision that rejects all norms. He argued that this cynicism is not only the opposite of the natural realization of humanity, but also a simple masking of instrumental objectives. Elster reminds us that in the natural state, no one cared for one another, a situation which only benefited the most powerful. Therefore, vulnerable people are better off when there are norms. He advocates that processes of deliberative democracy aimed at the inclusion of all the diversity of voices in decision-making. This has become one of the main positions of democratic theory. Indeed, this standpoint responds to the procedural ethics approach in which the goodness of decisions or agreements does not depend so much on their content itself, but on the procedure with which they have been reached. In these processes of deliberative dialogue, individuals not only add their preferences, but in the argumentation of the parties, these preferences are also transformed. This approach deepens the sense of democracy, for the promotion of more peaceful and inclusive societies, by overcoming the confrontation between different options. In voting, the different positions confront each other, and the majority is established democratically. In a deliberation, through arguments, the initial positions of those involved in decision-making can be modified, or even 
alternatives to those initial ones can appear and thus consensus can be achieved-a consensus that, far from eliminating differences, protects and promotes them.

\section{Conclusions}

The goal of this article was to provide evidence on the contributions made from some social theories towards the promotion of more sustainable and inclusive societies, in general, and towards the achievement of some of the UN's Sustainable Development Goals, in particular.

In order to achieve such aims, this article has drawn on contemporary social theories to exemplify how such research has provided citizens with the necessary science-based evidence to understand the reality around them and transform it. Moreover, it has shown that from No poverty (SDG1) to Peace, justice and strong institutions (SDG16), sociological research goes beyond descriptive analyses and diagnoses when it has social impact at its very core. Furthermore, the active demands of citizens regarding the need for research to yield results that contribute to the improvement of their life has led to the creation of spaces of dialogue between science and society, supported by the most excellent scientific programs. In such scenarios, a public sociology has emerged stronger than ever, drawing on the principle of co-creation to provide new knowledge that truly responds to citizens' needs.

Furthermore, this article has also presented some theories that never considered social impact, and which have deterred the improvement of societies. The argumentation provided in this manuscript supports the lack of scientific rigor behind such theories and proves their null contribution to the improvement of societies this far. By so doing, this article has stressed not only the importance of ensuring these two aspects from sociological theory (social impact and scientific soundness), but also of debunking any contributions that attack or threaten them. Only such a radical attitude can ensure that social theory keeps contributing towards the advancement of more sustainable societies. This, in turn, brings sociology back to its origins and to its ultimate goal: To provide citizens with the necessary knowledge to understand and govern themselves, improve their lives and live freely.

Funding: This research was funded by the European Union's Seventh Framework Programme (FP7/2007-2013) grant number 613202.

Conflicts of Interest: The authors declare no conflict of interest.

\section{References}

1. Weber, M. Economy and Society: An Outline of Interpretive Sociology; University of California Press: Oakland, CA, USA, 1978.

2. Parsons, T.; Dark, K.B. The Negro American; Houghton Mifflin Company: Boston, MA, USA, 1966.

3. Parsons, T. The Evolution of Societies, 1st ed.; Prentice Hall: New Jersey, NJ, USA, 1977.

4. Parsons, T. Action Theory and the Human Condition; Free Press: London, UK, 1978.

5. Parsons, T. The Social System; Free Press: Glencoe, IL, USA, 1951.

6. Marx, K. Capital; Penguin: London, UK, 1992.

7. Beck, U. Risk Society. Towards a New Modernity; SAGE Publications Ltd.: London, UK, 1992.

8. United Nations. THE 17 GOALS. Available online: https://sdgs.un.org/goals (accessed on 29 October 2020).

9. European Commission Horizon 2020. Available online: https://ec.europa.eu/programmes/horizon2020/en (accessed on 1 November 2020).

10. Flecha, R.; Radauer, A.; van den Besselaar, P. Monitoring the Impact of EU Framework Programmes: Expert Report; Publications Office of the European Union, Directorate-General for Research and Innovation: Brussels, Belgium, 2018; ISBN 9789279934711.

11. Mills, C.W. The Sociological Imagination; Oxford University Press: Oxford, UK, 2000; ISBN 9780199761128.

12. Burawoy, M. For Public Sociology. Am. Sociol. Rev. 2005, 70, 4-28. [CrossRef]

13. Collins, P.H. Going public. In Public Sociology. Fifteen Eminent Sociologists Debate Politics and the Profession in the Twenty-First Century; Clawson, D., Burawoy, M., Zussman, R., Misra, J., Gerstel, N., Stokes, R., Douglas, L.A., Eds.; University of California Press: Berkeley, CA, USA, 2007; pp. 101-113.

14. Tittle, C.R. The Arrogance of Public Sociology. Soc. Forces 2004, 82, 1639-1643. [CrossRef] 
15. Bhatt, J.; Bathija, P. Ensuring Access to Quality Health Care in Vulnerable Communities. Acad. Med. 2018, 93, 1271-1275. [CrossRef]

16. BBC News. Coronavirus: Government Sued over Care Home Deaths 'Disgrace'. 2020. Available online: https://www.bbc.com/news/uk-england-devon-53012565 (accessed on 26 November 2020).

17. Savage, M. Coronavirus: What's Going Wrong in Sweden's Care Homes? 2020. Available online: https: //www.bbc.com/news/world-europe-52704836 (accessed on 26 November 2020).

18. Levi-Montalcini, R. L'asso Nella Manica a Brandelli; Baldini \& Castoldi: Milan, Italy, 1998.

19. Erikson, E.H.; Erikson, J.M. The Life Cycle Completed (Extended Version); W. W. Norton: New York, NY, USA, 1998; ISBN 9780393347432.

20. De Beauvoir, S. Old Age; Deutsch, Weidenfeld and Nicolson: London, UK, 1972; ISBN 9780233959184.

21. Riccardi, A.; Prodi, R.; Sachs, J.D.; Dulkiewicz, A.; Hornby, S.A.; Castells, M.; Bokova, I.; Eyskens, M.; Pöttering, H.G.; Márquez, F.G.; et al. There Is No Future without the Elderly. Appeal to Re-Humanize Our Societies. No to a Selective Healthcare System. 2020. Available online: https://www.santegidio.org/pageID/37740/langID/en/THERE-IS-NO-FUTURE-WITHOUTTHE-ELDERLY-Appeal-to-rehumanize-our-societies.html (accessed on 26 November 2020).

22. Soler Gallart, M. Achieving Social Impact: Sociology in the Public Sphere; Springer: New York, NY, USA, 2017; ISBN 9783319602707.

23. Sen, A. Development as Freedom; Oxford University Press: Oxford, UK, 1999; ISBN 9780198297581.

24. Heckman, J.J.; García, J.L. Social Policy: Targeting programs effectively. Nat Hum Behav 2017, 1, 1-2. [CrossRef]

25. García, J.L.; Heckman, J.J.; Leaf, D.E.; Prados, M.J. Quantifying the Life-Cycle Benefits of an Influential Early-Childhood Program. J. Polit. Econ. 2020, 128, 2502-2541. [CrossRef]

26. Vishkaie, R. The pandemic, war, and sanctions: Building resilience for the digital divide in education. Interactions 2020, 27, 36-37. [CrossRef]

27. Bourdieu, P.; Passeron, J.-C. Les Héritiers: Les Étudiants et la Culture; Les Éditions de Minuit: Paris, France, 1964; ISBN 9782707338129.

28. Bourdieu, P. La Distinction: Critique Sociale du Jugement; Les Éditions de Minuit: Paris, France, 1979.

29. López de Aguileta, G.; Torras-Gómez, E.; García-Carrión, R.; Flecha, R. The emergence of the language of desire toward nonviolent relationships during the dialogic literary gatherings. Lang. Educ. 2020, 1-16. [CrossRef]

30. Sanchez Aroca, M. Voices inside schools-La Verneda-Sant Martí: A school where people dare to dream. Harv. Educ. Rev. 1999, 69, 320-336. [CrossRef]

31. Ruiz-Eugenio, L.; Roca Campos, E.; León-Jiménez, S.; Ramis-Salas, M. Child Well-being in Times of Confinement: The Impact of Dialogic Literary Gatherings Transferred to Homes. Front. Psychol. 2020, 11, 2675. [CrossRef]

32. Roca, E.; Melgar, P.; Gairal-Casadó, R.; Pulido-Rodríguez, M.A. Schools That 'Open Doors' to Prevent Child Abuse in Confinement by COVID-19. Sustainability 2020, 12, 4685. [CrossRef]

33. Berger, P.L.; Luckmann, T. The Social Construction of Reality: A Treatise in the Sociology of Knowledge; Doubleday: New York, NY, USA, 1966.

34. Aiello, E.; Amador-López, J.; Munté-Pascual, A.; Sordé-Martí, T. Grassroots Roma Women Organizing for Social Change: A Study of the Impact of ‘Roma Women Student Gatherings. Sustain. Sci. Pract. Policy 2019, 11, 4054. [CrossRef]

35. Beck-Gernsheim, E.; Butler, J.; Puigvert, L. Women \& Social Transformation; Peter Lang: Frankfurt, Germany, 2003.

36. Racionero-Plaza, S.; Ugalde, L.; Merodio, G.; Gutiérrez-Fernández, N. “Architects of Their Own Brain." Social Impact of an Intervention Study for the Prevention of Gender-Based Violence in Adolescence. Front. Psychol. 2019, 10, 3070. [CrossRef]

37. Puigvert Mallart, L.; Flecha García, R.; Racionero-Plaza, S.; Sordé-Martí, T. Socioneuroscience and its contributions to conscious versus unconscious volition and control. The case of gender violence prevention. AIMS Neurosci. 2019, 6, 204-218. [CrossRef]

38. Torras-Gómez, E.; Puigvert, L.; Aiello, E.; Khalfaoui, A. Our Right to the Pleasure of Falling in Love. Front. Psychol. 2019, 10, 3068. [CrossRef] 
39. Flecha, R.; Puigvert, L.; Rios, O. The New Alternative Masculinities and the Overcoming of Gender Violence. RIMCIS 2013, 2, 88-113. [CrossRef]

40. Gómez, J. Radical Love: A Revolution for the 21st Century; Peter Lang: Frankfurt, Germany, 2015; ISBN 9781433126499.

41. Connell, R. Masculinity research and global change. Masc. Soc. Chang. 2012, 1, 4-18. [CrossRef]

42. Rios-González, O.; Peña Axt, J.C.; Duque Sánchez, E.; De Botton Fernández, L. The Language of Ethics and Double Standards in the Affective and Sexual Socialization of Youth. Communicative Acts in the Family Environment as Protective or Risk Factors of Intimate Partner Violence. Front. Sociol. 2018, 3, 19. [CrossRef]

43. Vidu, A.; Tomás, G. The Affirmative "Yes". Sexual Offense Based on Consent. Masc. Soc. Chang. 2019, 8, 91-112. [CrossRef]

44. Springora, V. Le Consentement; Grasset: Paris, France, 2020; ISBN 9782246822691.

45. Le Monde. Un Appel pour la Révision du Code Pénal à Propos des Relations Mineurs-Adultes; Le Monde: Paris, France, 1977.

46. Foucault, M.; Danet, J.; Hahn, P.; Hocquenghem, G. La loi de la pudeur-Entretien sur France Culture (1978). Fou d'enfance 1979, 37, 69-82.

47. Ansart, G. Condorcet, Social Mathematics, and Women's Rights. Eighteenth Century Stud. 2009, 42, $347-362$. [CrossRef]

48. Verjus, A. Les critiques de l'ordre du genre à l'époque de la révolution française. Ethnol. Fr. 2019, 174, 229-242. [CrossRef]

49. Packham, C. Genre and the Mediation of Political Economy in Edmund Burke's Reflections on the Revolution in France and Mary Wollstonecraft's A Vindication of the Rights of Men. Eighteenth Century 2019, 60, 249-268. [CrossRef]

50. Horton, R. The COVID-19 Catastrophe: What's Gone Wrong and How to Stop It Happening Again; John Wiley \& Sons: Hoboken, NJ, USA, 2020; ISBN 9781509546473.

51. You, J. Lessons from South Korea's Covid-19 policy response. Am. Rev. Public Admin. 2020, 50, 801-808. [CrossRef]

52. Duong, D.M.; Le, V.T.; Ha, B.T.T. Controlling the COVID-19 Pandemic in Vietnam: Lessons From a Limited Resource Country. Asia. Pac. J. Public Health 2020, 32, 161-162. [CrossRef]

53. Humanity Tested. Available online: https://www.nature.com/articles/s41551-020-0553-6 (accessed on 26 November 2020).

54. Merton, R.K. The Matthew effect in science. The reward and communication systems of science are considered. Science 1968, 159, 56-63. [CrossRef]

55. Wright, E.O. Envisioning Real Utopias; Verso: London, UK, 2010; Volume 98.

56. Redondo, G.; Santa Cruz, I.; Rotger, J.M. Why Mondragon? Analyzing What Works in Overcoming Inequalities. Qual. Inq. 2011, 17, 277-283. [CrossRef]

57. Habermas, J. Between Facts and Norms-Contributions to a Discourse Theory of Law and Democracy; The MIT Press: Cambridge, MA, USA, 1996.

58. Elster, J. Deliberative Democracy; Cambridge University Press: New York, NY, USA, 1998; ISBN 9780521596961.

59. Beck, U.; Giddens, A.; Lash, S. Reflexive Modernization: Politics, Tradition and Aesthetics in the Modern Social Order; Stanford University Press: Redwood City, CA, USA, 1994; ISBN 9780804724722.

60. United Nations Goal 16. Available online: https://sdgs.un.org/goals/goal16 (accessed on 31 October 2020).

61. Derrida, J. De la Grammatologie; Minuit: Paris, France, 1967.

62. Foucault, M. Discipline and Punish: The Birth of the Prison; Pantheon Books: New York, NY, USA, 1977; ISBN 9780394499420.

63. Nietzsche, F. On the Genealogy of Morality; Cambridge University Press: New York, NY, USA, 1994.

64. Elster, J. Nuts and Bolts; Cambridge University Press: New York, NY, USA, 1989.

Publisher's Note: MDPI stays neutral with regard to jurisdictional claims in published maps and institutional affiliations. 